\title{
Musaespora kalbii (lichenized Ascomycetes: Melanommatales), a new foliicolous lichen with a pantropical distribution
}

\author{
Robert Lücking and Emmanuël Sérusiaux
}

\begin{abstract}
Lücking, R. \& Sérusiaux, E. 1997. Musaespora kalbii (lichenized Ascomycetes: Melanommatales), a new foliicolous lichen with a pantropical distribution. - Nord. J. Bot. 16: 661-668. Copenhagen. ISSN 0107-055X.

Musaespora kalbii sp. nov. is a foliicolous lichen distinguished by its unilocular, blackish brown ascocarps and campylidia. It is known from Costa Rica, French Guiana, the West Indies, Madagascar, and Papua New Guinea. The species is most common at medium elevations $(500-1500 \mathrm{~m})$ and prefers semi-open situations. The genus Musaespora seems to be related to the genera Architrypethelium, Megalotremis and Anisomeridium. Its campylidia are assumed to be derived from pycnidia.
\end{abstract}

R. Lücking, Abteilung Spezielle Botanik, Universität Ulm, D-89069 Ulm, Germany. E. Sérusiaux, Research Associate F. N. R. S., Department of Botany, University of Liège, Sart Tilman B22, B-4000 Liège, Belgium.

\section{Introduction}

The genus Musaespora was introduced by Aptroot \& Sipman (1993) to accomodate three new species of pyrenocarpous lichens producing campylidia as anamorphs and further characterized by their large, 1-septate, slightly curved ascospores. Later it turned out that a foliicolous, previously described species actually belonging to Musaespora is Astrothelium epiphyllum R. Sant. (Santesson 1952), now recombined as Musaespora epiphylla (R. Sant.) R. C. Harris (Harris 1995). Musaespora was included in the Melanommatales and was thought to belong to the Aspidotheliaceae Räsänen ex J. C. David \& D. Hawksw., mainly because of its hamathecial structure, ascus type, and ascospores (Aptroot \& Sipman 1993).

The present paper deals with a further new species of Musaespora, already mentioned as Genus sp. B (known only from its campylidia) and as Musaespora sp. in earlier publications (Lücking 1992; Aptroot \& Sipman 1993). The species can now be formally described, as abundant material with ascocarps and campylidia is available. The plentiful collections also demonstrate that the populations from the Neotropics (Costa Rica, West Indies) and the Paleotropics (Madagascar, Papua New Guinea) are conspecific. The systematic affinities of the genus and the phylogenetic origin of the campylidia are discussed.

\section{Musaespora kalbii R. Lücking \& Sérusiaux sp. nov.}

Thallus epiphyllus, tenuis, laevigatus, cinereo-aeneus, nitidulus. Perithecia uniloculata, in thallo immersa sed erumpentia, verruciformia, 0.3-0.6 mm diam., fusco-nigra. Paries externus haud bene evolutus, paries internus prosoplectenchymaticus. Asci bitunicati, I-, oblongo-ellipsoidei, octospori. Ascosporae oblongo-ellipsoideae, rectae ad leviter curvatae, uniseptatae, parietibus crassis instructae, incoloratae, 60-85(-130) $\times 12-20 \mu \mathrm{m}$. Campylidia parte basali verruciformi conidia continente et parte apicali cassidi simili composita; pars basalis 0.25 $0.35 \mathrm{~mm}$ diam., pars apicalis usque ad $0.5 \mathrm{~mm}$ alta, fus-

\footnotetext{
Accepted 29-2-1996

(C) NORDIC JOURNAL OF BOTANY
} 
co-nigra, leviter striata. Conidia ellipsoidea vel guttiformia, simplicia, 5-8 $\times 2.5-3.5 \mu \mathrm{m}$. Alga ad Trentepohliaceas (Cephaleuros ?) pertinens. - Figg. 1-2.

Type: Costa Rica, Limon, Braulio Carrillo National Park, Section Quebrada Gonzales, »Botarrama« trail at the Rio Sucio, $10^{\circ} 12^{\prime} \mathrm{N}, 83^{\circ} 55^{\prime} \mathrm{W}, 480 \mathrm{~m}$ alt., primary submontane rain forest, Oct. 1991, R. Lücking 91-1419 (ULM holotype, VBI, hb. Lücking isotypes).

Thallus epiphyllous, $10-30 \mathrm{~mm}$ in diam., smooth, greyish-bronze, slightly nitidous and often with a metallic glance, $10-15(-20) \mu \mathrm{m}$ thick, with a 5-7 $\mu \mathrm{m}$ thick corticiform layer made of colourless, agglutinated hyphae; prothallus often developed, membranaceous, 0.1-0.5 $\mathrm{mm}$ broad, usually colourless but appearing dark due to the leaf colour shining through.

Perithecia unilocular, immersed in the thallus but erumpent, $0.3-0.6 \mathrm{~mm}$ in diam., applanate to prominent, wart-shaped, their top sometimes slightly impressed around the ostiole, dark brown to blackish brown at the top, pale yellowish brown to greyish brown on their lateral and basal parts due to a thallus layer which usually ruptures into $4(-5)$ triangular lobes. Outer perithecial wall developed only in the upper part of the perithecium, laterally covered by a 7-10 $\mu \mathrm{m}$ thick corticiform thallus layer, apically dark brown to blackish brown, its lower part fused with the inner wall; a continuous algal layer present below the cortex and reaching up to the periphery of the outer wall; inner wall 10-17 $\mu \mathrm{m}$ thick, prosoplectenchymatous, colourless, with a »tissue « of very loosely interwooven, up to $3 \mu \mathrm{m}$ thick hyphae present laterally between the outer and the inner wall. Hamathecium consisting of $c .0 .7 \mu \mathrm{m}$ thick, richly branched and anastomosing paraphysoids (trabeculate pseudoparaphyses; cf. Aptroot \& Sipman 1993), in the upper part up to the ostiole inspersed with numerous oil droplets. Asci bitunicate, I-, oblong-ellipsoid, 155-170 $\times$ 45-50 $\mu \mathrm{m}$, with a small, narrow stalk and a distinct tholus provided with an ellipsoid, c. $10 \mu \mathrm{m}$ wide ocular chamber; outer layer 2.5-3 $\mu \mathrm{m}$ thick, inner layer up to $5 \mu \mathrm{m}$ thick at its apex; above the ocular chamber with a thin, caplike structure; no further details visible when stained in Brilliant chresyl blue, Chlorazole black, Cotton blue, or Congo red (cf. Eriksson 1981). Ascospores 8 per ascus, oblong-ellipsoid, straight to slightly curved, 1-septate, thick-walled, colourless, $60-85(-130) \times 12-20 \mu \mathrm{m}$, sometimes broken into two halfs, their ascoplasm surface provided with crystals.

Campylidia composed of a basal, wart-shaped pycnidial part apically protruding the conidia, and an apical, ear- or helmet-shaped lobe often provided with a pronounced tip indicating its opening when seen from above; basal part $0.25-0.35 \mathrm{~mm}$ in diam., the apical lobe up to $0.5 \mathrm{~mm}$ high, its surface dark brown to blackish brown, slightly striate in longitudinal direction. Basal wart-shaped part provided with an ovate chamber almost entirely coated with a conidiogeneous layer except for the most apical region; conidiophores simple, c. 15$20 \mu \mathrm{m}$ long and $0.7 \mu \mathrm{m}$ thick; opening developed as a narrow channel, coated with rather long, simple or slightly branched, $1.5 \mu \mathrm{m}$ thick hyphae, the channel running into the cavity sheltered by the lower side of the helmet-shaped lobe. Conidia numerous, filling both the chamber of the basal part and the cavity below the lobe, usually hold together by a colourless, gelatinous mass, ellipsoid to drop-shaped, simple, 5-8 $\times 2.5-3.5 \mu \mathrm{m}$. Figs 1-2).

Photobiont: a species of Trentepohliaceae (generic position not determined), with cells angular-rounded, $6.5-13.5 \times 2.5-6 \mu \mathrm{m}$, irregularly arranged in branched and anastomosing threads, apparently forming several layers, perhaps related to the genus Cephaleuros.

Etymology: This new species is dedicated to Dr Klaus Kalb, a distinguished lichenologist who has contributed very much to the knowledge of tropical lichens.

Comments: Musaespora kalbii is easily characterized by its smooth, greyish-bronze thallus, its blackishbrown, unilocular perithecia and its blackish-brown, ear- or helmet-shaped campylidia. The populations from Costa Rica, from the West Indies and from Madagascar are rather uniform with respect to their apothecial morphology and anatomy. The material from Papua New Guinea is somewhat more variable, especially its ascospores which can reach up to $130 \mu \mathrm{m}$ in lenght, but we think that these differences are not worth any taxonomic rank.

M. kalbii is obviously close to M. epiphylla (= Astrothelium epiphyllum ), which differs by its multiloculate perithecia which can be up to $1.5 \mathrm{~mm}$ broad.

Distribution: Musaespora kalbii is at present known from rather distant parts of the tropics, viz. Costa Rica, the West Indies, French Guiana, Madagascar, and Papua New Guinea. This indicates a wide tropical distribution, and the species will most probably be found in other regions as well. M. kalbii has been found only on living leaves. It occurs throughout a wide altitudinal range $(0-2500 \mathrm{~m})$ but is most common at medium elevations $(500-1500 \mathrm{~m})$. The species seems to prefer semiopen situations, such as small, natural light gaps in virgin rain forest (Lücking 1994), forest margins or disturbed vegetation. It has also been found in the forest canopy on some occasions (Lücking 1995a). M. kalbii is often associated with other pyrenocarpous lichens, such as species of Aspidothelium and Phyllobathelium (Aptroot \& Sipman 1993; Lücking 1994). Generally, the species seems to be associated with a rather high fo- 

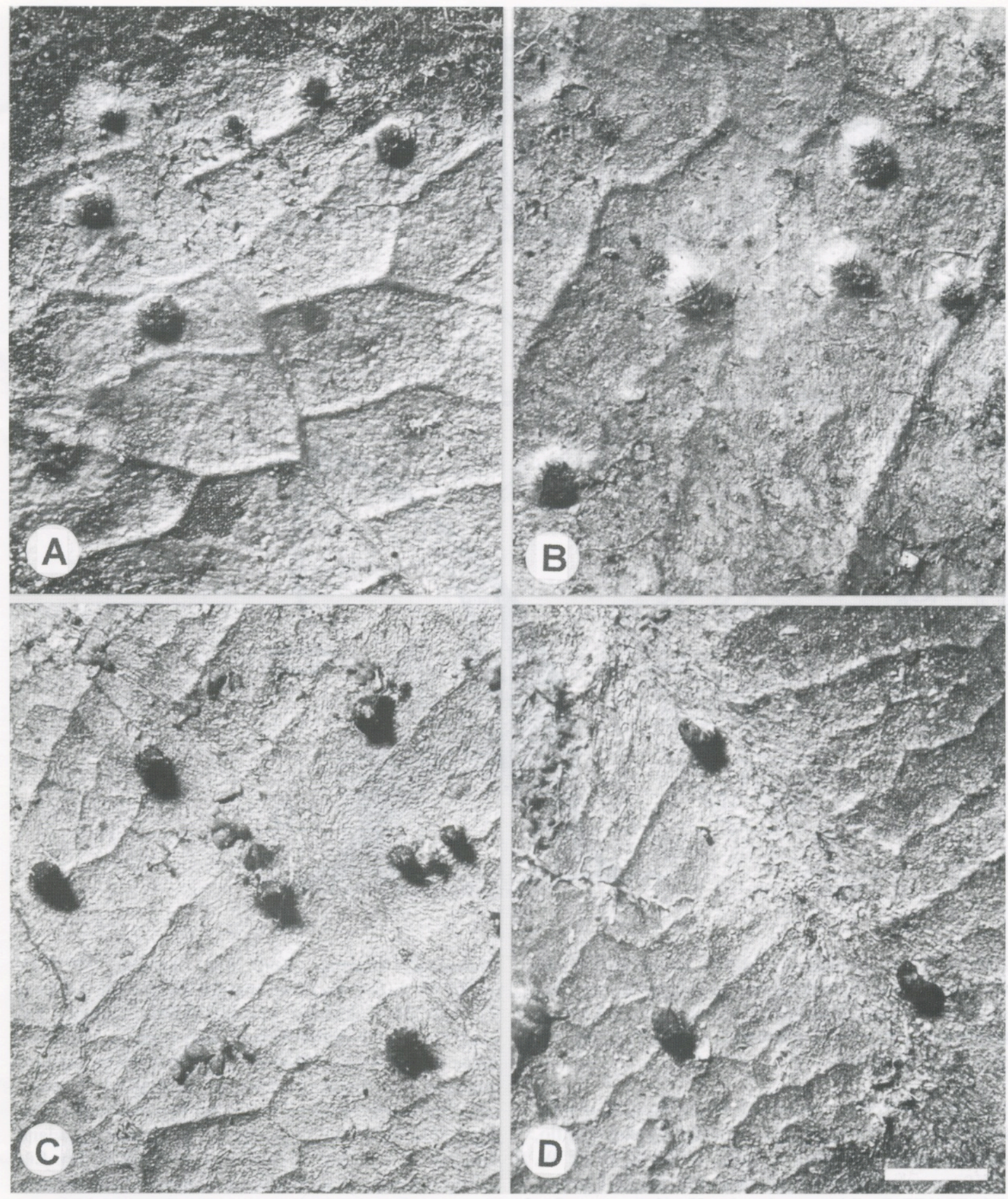

Fig. 1. Musaespora kalbii, general habit. - A-B. Thallus with perithecia (isotype (hb. Lücking)). - C-D. Thallus with welldeveloped campylidia - Costa Rica, San Ramon, Lücking 91-1427 (hb. Lücking). Scale bar =1 mm. 

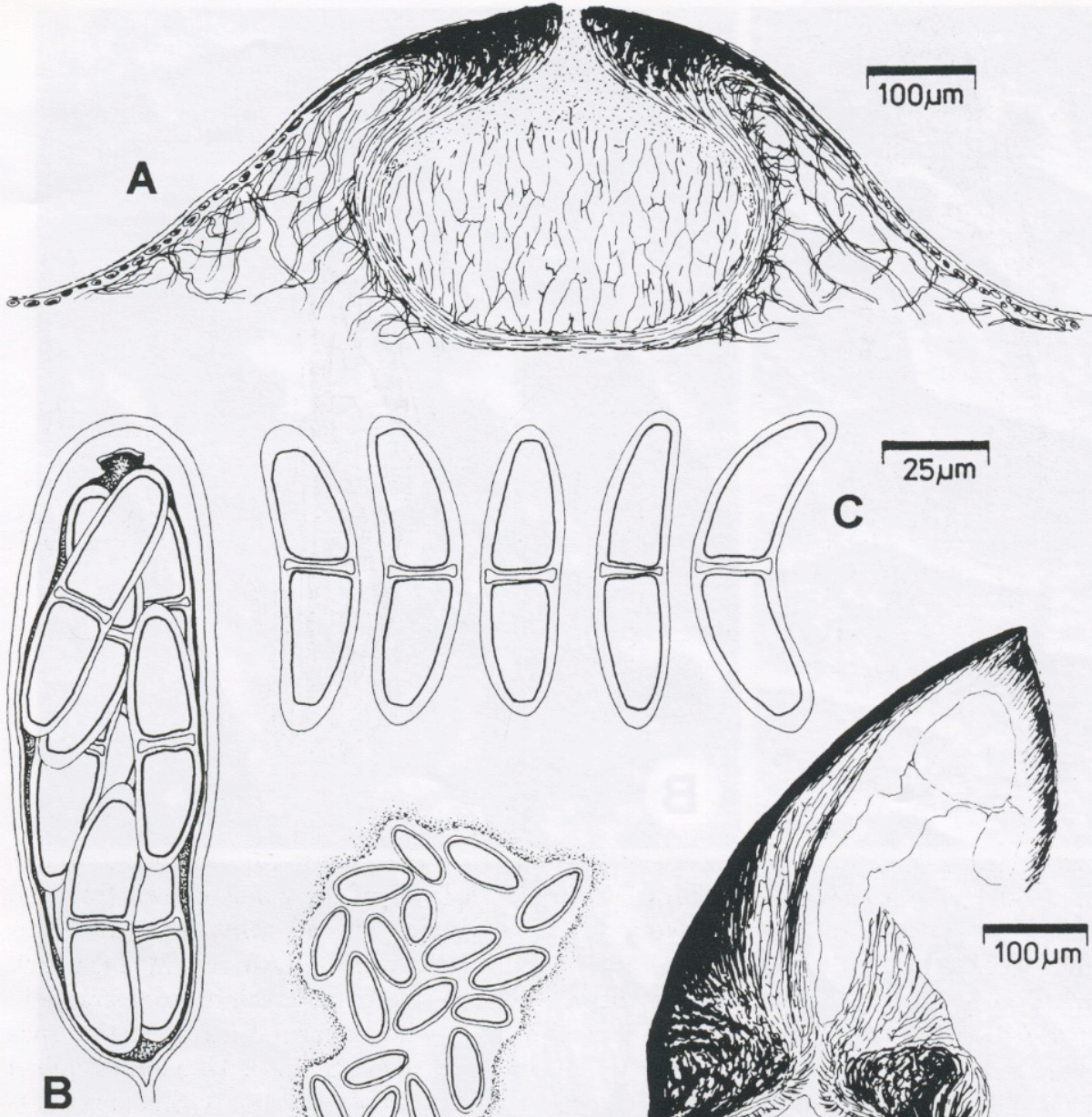
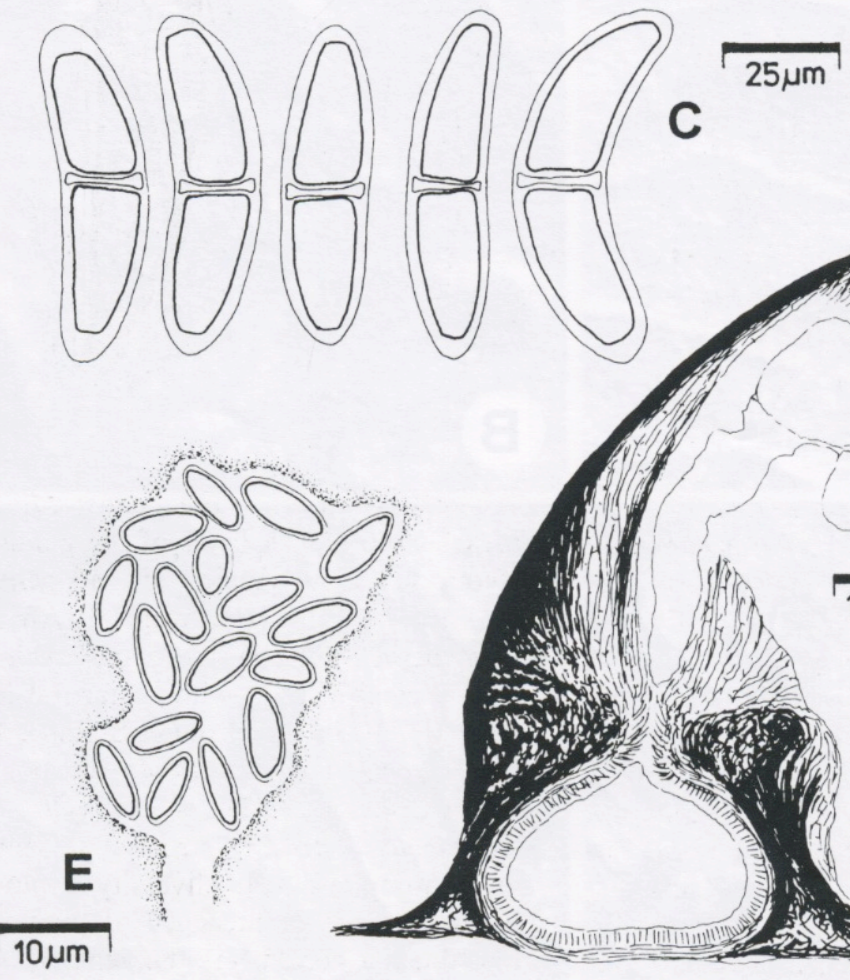

Fig. 2. Musaespora kalbii, anatomy. - A. Section through perithecium, showing external and internal wall, loosely interwooven lateral hyphae, and hamathecium with paraphysoids and oil droplets. - B. Mature ascus, showing ocular chamber. - C. Ascospores. D. Section through a campylidium, showing basal wartshaped part and helmetshaped apical lobe, its cavity filled with numerous conidia. - E. Conidia, sticked together in a gelatinous mass. - A-C . Holotype (ULM); D-F. Costa Rica, San Ramon, 91-1427 (hb. Lücking). liicolous lichen diversity (observed in the collections from Costa Rica, French Guiana, Madagascar, and $\mathrm{Pa}-$ pua New Guinea), often found in semi-open, but nevertheless partly protected microsites (Aptroot \& Sipman 1993; Lücking 1994).

Additional specimens examined: Costa Rica. San José: Braulio Carillo National Park, former section Carillo, »Botella« trail, near the Rio Sucio, $10^{\circ} 09^{\prime} \mathrm{N}, 83^{\circ} 58^{\prime} \mathrm{W}$, c. $750 \mathrm{~m}$, primary lower montane rain forest, Lücking 91-3077 (GZU); ibid., section La Hondura, near San Gerónimo, $10^{\circ} 02^{\prime} \mathrm{N}, 84^{\circ} 00^{\prime} \mathrm{W}$, c. $1500 \mathrm{~m}$, primary montane rain forest and forest margin, Lücking 92-4786 (STU). Alajuela: Arenal Forest Reserve, near Fortuna, $10^{\circ} 28^{\prime} \mathrm{N}, 84^{\circ} 40^{\prime} \mathrm{W}$, c. $500 \mathrm{~m}$, primary lower montane rain forest, Lücking 91-2158 (UPS). Alberto Brenes
Biological Reserve, near San Ramon, $10^{\circ} 13^{\prime} \mathrm{N}$, $84^{\circ} 36^{\prime} \mathrm{W}$, c. $800 \mathrm{~m}$, forest margin along road, Lücking 91-1427 (hb. Lücking), 91-1430 (UPS). Cartago: Tapanti National Wildlife Refuge, near Cartago, „Oropendula « trail, $9^{\circ} 46^{\prime} \mathrm{N}, 83^{\circ} 46^{\prime} \mathrm{W}$, c. $1200-1300 \mathrm{~m}$, primary montane rain forest, Lücking 91-3978 (CR). Puntarenas: Corcovado National Park, Osa Peninsula, »Los Patos «, $8^{\circ} 34^{\prime} \mathrm{N}, 83^{\circ} 31^{\prime} \mathrm{W}$, c. $50-150 \mathrm{~m}$, primary lowland rain forest, Lücking 92-3165 (M, NY, ULM, hb. Lücking). Limon: Braulio Carillo National Park, section Quebrada Gonzales, »Botarrama« trail, near the Rio Sucio, $10^{\circ} 12^{\prime} \mathrm{N}, 83^{\circ} 55^{\prime} \mathrm{W}$, c. $480 \mathrm{~m}$, primary submontane rain forest, Lücking 91-174 (CR), 91-802 (G), 91-1420 (NY), 91-1421 (hb. Kalb), 91-1424 (LG), 92-2506 (B); ibid., canopy layer, Lücking 91-262 (M), 92-4849 (LG); ibid., forest margin, Lücking 92-2486 (UPS). Heredia: 
Fig. 3. A. Aspidothelium fugiens, mature ascus with paraphyses, ascospores. - B. A. cinerascens (type speciesof Aspidothelium), mature ascus with paraphyses, ascospores. - A. Costa Rica, Lücking 92-430 (hb. Lücking); B. Costa Rica, Lücking 92-469 (hb. Lücking).

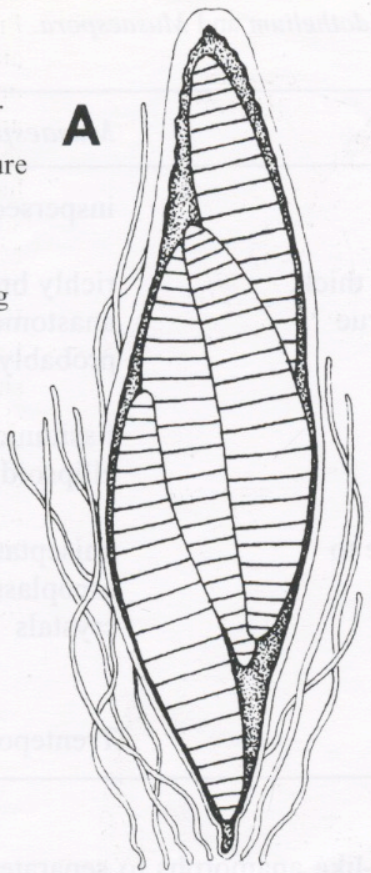

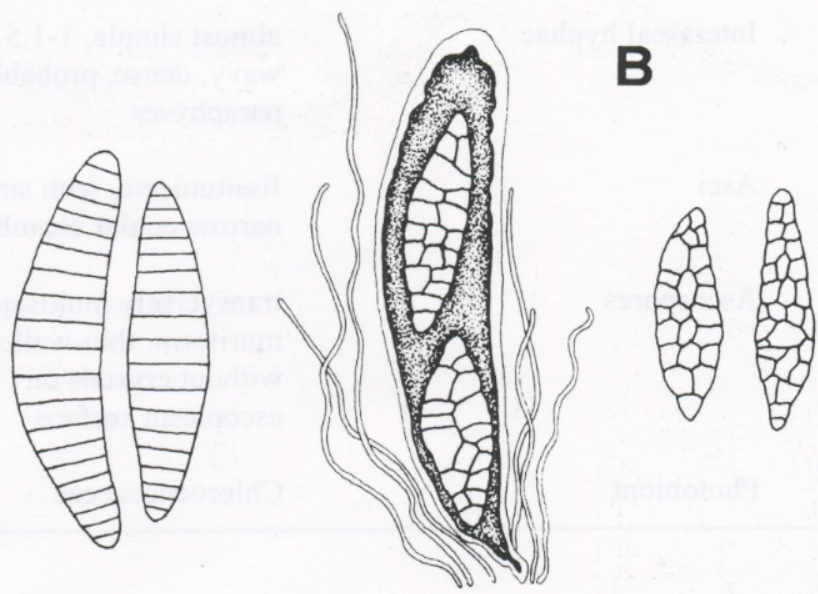

\section{$25 \mu \mathrm{m}$}

La Selva Protection Zone (O.T.S.), near Puerto Viejo de Sarapiquí, $10^{\circ} 26^{\prime} \mathrm{N}, 84^{\circ} 03^{\prime} \mathrm{W}$, c. 50-100 m, swamp forest on SUA/CCC trails, Lücking 91-5398 (STU). Tortuguero National Park, Cerro Tortuguero, $10^{\circ} 35^{\prime} \mathrm{N}$, $83^{\circ} 31^{\prime} \mathrm{W}$, c. 0-100 $\mathrm{m}$, primary lowland rain forest, Lücking 92-2540 (BM), 92-2596 (STU). - Guadeloupe. Basse-Terre, starting point of the track going up to the »Mamelle du Petit Bourg«, near the road D23, $580 \mathrm{~m}$ alt., more or less disturbed rain forest at the bottom of a small valley, IV. 1995, Sérusiaux s. n. (LG). - St. Lucia. Road Castries-Dennery, »Barre de l'Isle«, near the touristic hut, 250-300 m alt., disturbed rain forest, II. 1993, Sérusiaux s. n. (LG). - French Guiana. Sinnamary: Piste de St. Elie, 95 km NW of Cayenne and 47 $\mathrm{km}$ NW of Kourou near Sinnamary, $5^{\circ} 20^{\prime} \mathrm{N}, 53^{\circ} 02^{\prime} \mathrm{W}$, $50 \mathrm{~m}$ alt., very slightly disturbed tropical lowland rain forest along road, on leaves around the station, V. 1995, Lücking s. n. (hb. Lücking).

Madagascar. Tamatave Province: Moramanga, c. 8 $\mathrm{km} \mathrm{E}$ of Beforona, $18^{\circ} 57^{\prime} \mathrm{S}, 48^{\circ} 30^{\prime} \mathrm{E}$, slightly disturbed forest, XI. 1994, Scheidegger s. n. (hb. Scheidegger).

Papua New Guinea. Central Province: Sogeri Plateau, Varirata National Park, c. 920 m alt., rainforest, 1987, de Sloover s. n. (LG). Eastern Highlands Province: Mt. Gahavisuka Provincial Park, 11 km N of Goroka, along trail to lookout, c. 2300-2450 m alt., little disturbed mossy mountain forest, 11. VIII. 1992, Sérusiaux 13762-59 (LG). Madang Province: Wasabamal logging area, c. $25 \mathrm{~m}$ alt., tropical lowland rain forest, 1987, Aptroot $17381 \mathrm{f}$ (hb. Aptroot).
General remarks on the genus: Musaespora kalbii is thus far the only species of the genus known from the Neotropics. Two species, viz. M. epiphylla and M. kalbii, are known from tropical Africa (Madagascar), whereas in S-E Asia, the genus exhibits comparatively high diversification, with so far not less than five species: $M$. coccinea Aptroot \& Sipman, M. gigas (Zahlbr.) R. C. Harris (=M. corticola Aptroot \& Sipman) (Aptroot \& Sipman 1993), M. epiphylla, M. kalbii, and $M$. kassamensis Sérus. (Aptroot et al. 1997). In spite of the great morphological diversity (smooth to verrucose thalli, absence or presence of pigments, unilocular or multilocular perithecia), the genus is very homogeneous because of its anatomical features (hamathecium, ascus type, and ascospores) and its campylidia and conidia produced by those campylidia (Aptroot \& Sipman 1993).

Aptroot \& Sipman (1993: 123) refer Musaespora to the Aspidotheliaceae, because of its »... thick-walled, multilayered ascus, its thin, anastomosing hamathecium filaments, and its large, colourless, euseptate spores «. We believe that this placement is doubtful, as (cf. Fig. 3 and Tab. 1): (1) the multilayered, thick-walled ascus is a rather widespread feature in pyrenocarpous ascomycetes (Eriksson 1981); (2) the asci of Aspidothelium Vainio (the type genus of the family) have a small, narrow ocular chamber; (3) the paraphyses of Aspidothelium are almost simple, 1-1.5 $\mu \mathrm{m}$ thick, somewhat wavy, and densely packed; (4) the ascospores of Aspidothelium are thin-walled, transversely multiseptate to muriform and lack crystals on their ascoplasm surface; (5) 
Tab. 1. Comparison of morphological and anatomical characters of Aspidothelium and Musaespora.

\begin{tabular}{lll}
\hline & Aspidothelium & Musaespora \\
\hline Hamathecium & clear & inspersed with oil droplets \\
Interascal hyphae & $\begin{array}{l}\text { almost simple, } 1-1.5 \mu \mathrm{m} \text { thick, } \\
\text { wavy, dense, probably true } \\
\text { paraphyses }\end{array}$ & $\begin{array}{l}\text { richly branched and } \\
\text { anastomosing, } 0.7 \mu \mathrm{m}, \\
\text { probably paraphysoids }\end{array}$ \\
Asci & $\begin{array}{l}\text { fissitunicate, with small, } \\
\text { narrow ocular chamber }\end{array}$ & $\begin{array}{l}\text { fissitunicate, with broad, } \\
\text { ellipsoid ocular chamber }\end{array}$ \\
Ascospores & $\begin{array}{l}\text { transversely multiseptate to } \\
\text { muriform, thin-walled, } \\
\text { without crystals on } \\
\text { ascoplasm surface }\end{array}$ & $\begin{array}{l}\text { uniseptate, thick-walled, } \\
\text { ascoplasm surface with } \\
\text { crystals }\end{array}$ \\
& Chlorococcaceae & Trentepohliaceae \\
\hline
\end{tabular}

the photobionts belong to different families (Trentepohliaceae vs. Chlorococcaceae). One could argue that a large variation in ascospore septation, similar to the "couple« Aspidothelium-Musaespora, occurs in other taxa as well, such as in the genus Asterothyrium Müll. Arg., or in the couple Linhartia Sacc. \& P. Syd. - Psorotheciopsis Rehm. In these groups, however, the species are held together by their similar thallus and apothecial anatomy and clearly form monophyletic taxa (Santesson 1952; Henssen \& Lücking, in prep.).

A striking feature of all species of Musaespora is the occurrence of crystals (needle-shaped or polyhedral, best seen under polarized light) on the ascoplasm surface of their ascospores. Such crystals are also observed in four other pyrenocarpous lichen genera (Aptroot et al. 1997): in the type species of Architrypethelium Aptroot (A. seminudum (Mont.) Aptroot), of Megalotremis Aptroot (M. verrucosa (Makhija \& Patwardhan) Aptroot), of Phyllobathelium (Müll. Arg.) Müll. Arg. (P. epiphyllum (Müll. Arg.) Müll. Arg.), and in Thelenella paraguayensis Malme. Their occurrence might be of systematic importance, especially as three of the mentioned genera (Architrypethelium, Megalotremis, and Musaespora) also have rather large ascospores with few transverse septa and without apical thickenings. These genera might be closely related and form a monophyletic group, which might be referred either to the Trypetheliaceae Zenker (Aptroot 1991) or to the Monoblastiaceae (Harris 1995). Actually, Musaespora is in several respects very close to Anisomeridium (Müll. Arg.) M. Choisy, and Megalotremis is considered as a synonym of the latter by Harris (1995). Harris (1995) even questiones the systematic value of campy- lidia-like anamorphs to separate Musaespora from Anisomeridium, but we are convinced that the campylidia are a distinctive feature of Musaespora, well supported by the uniform hamathecial structure of all Musaespora species.

Remarks on the origin of campylidia: The phylogeny and biological role of campylidia, known from five different families in three non-related orders, is discussed in detail in recent papers (Lücking 1995b; Sérusiaux 1995). Whereas in some taxa, for example in the genus Badimia Vězda, an ontogenetic or phylogenetic relationship between campylidia and apothecia is assumed (Malcolm \& Vězda 1994; Sérusiaux 1986, 1995; Vězda 1986), in Musaespora the campylidia seem to be derived from pycnidia, although their anatomy is somewhat reminescent of that of the perithecia. Indeed, if the apical, ear- to helmet-shaped lobes were not present, the basal wart-shaped part of the campylidia could be easily regarded as a »normal« pycnidium (Fig. 4). However, in several pyrenocarpous taxa, perithecia and pycnidia are strikingly similar, indicating that both organs might have a common phylogenetical origin, possibly separated during evolution because of sexual specialization or asexual dispersal purposes. Thus the campylidia of Musaespora could be regarded as secondarily derived from perithecia via pycnidia. The unidirectional orientation of the campylidia often observed on thalli of different taxa (Aptroot \& Sipman 1993; Lücking 1995b; Sérusiaux 1986, 1995) is less frequently observed in Musaespora kalbii, indicating that their orientation may be induced not only by the water flow on the leaf, but also by additional, still undetermined factors. 


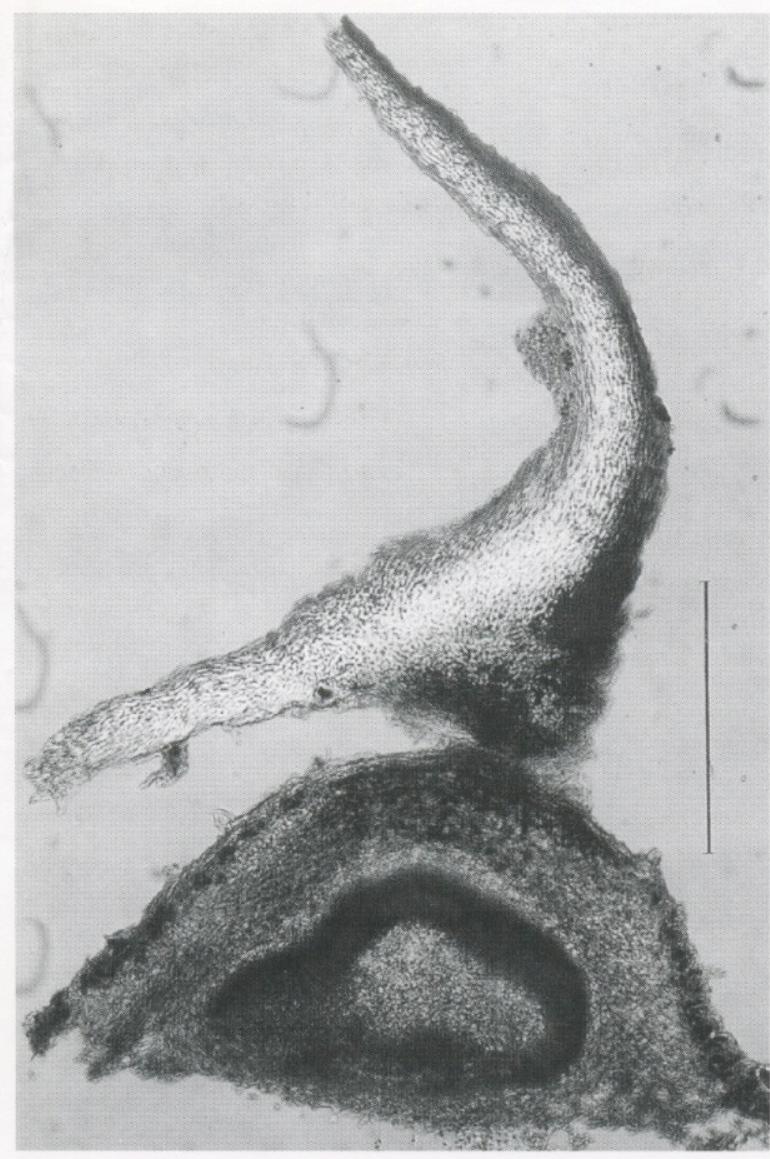

Fig. 4. Musaespora epiphylla, cross section through a campylidium showing the basal "pycnidial" part and the apical ear- to helmet-shaped lobe attached to the upper part of the "pycnidium«. Mounted in LCB. - Papua New Guinea, Sérusiaux 13555-50 (LG). Scale bar $=100 \mu \mathrm{m}$.

Acknowledgements - We would like to express our gratitude to Prof. J. Lambinon for the revision of the Latin diagnosis.

\section{References}

Aptroot, A. 1991. A monograph of the Pyrenulaceae (excluding Anthracothecium and Pyrenula) and the Requienellaceae, with notes on the Pleomassariaceae, the Trypetheliaceae and Mycomicrothelia (lichenized and non-lichenized Ascomycetes). - Bibl. Lichenol. 44: 1-186.

- \& Sipman, H. J. M. 1993. Musaespora, a genus of pyrenocarpous lichens with campylidia, and other additions to the foliicolous lichen flora of New Guinea. - Lichenologist 25: 121-135.

- , Diederich, L., Sérusiaux, E. \& Sipman, H. J. M. 1997. Lichens and lichenicolous Fungi from New Guinea - Bibl. lichenol. 64: 1-220.

Eriksson, O. 1981. The families of bitunicate ascomycetes. Opera Bot. 60: 1-220.

Harris, R. C. 1995. More Florida Lichens. - New York Botanical Garden, Bronx, New York.

Lücking, R. 1992. Foliicolous lichens - a contribution to the knowledge of the lichen flora of Costa Rica, Central America. - Beih. Nova Hedwigia 104: 1-179.

- 1994. Foliikole Flechten und ihre Mikrohabitatpräferenzen in einem tropischen Regenwald in Costa Rica. - Diss., Fak. Naturw. Univ. Ulm.

- 1995a. Foliikole Flechten auf Cecropiaceen im Kronendach eines tropischen Regenwaldes. - Bibl. Lichenol. 58: 261-274.

- 1995b. Additions and corrections to the knowledge of the foliicolous lichen flora of Costa Rica. The family Arthoniaceae, with notes on the genus Stirtonia. - Lichenologist 27: $127-153$.

Malcolm, W. M. \& Vězda, A. 1994. Badimiella serusiauxii, a new genus and species of foliicolous lichens from New Zealand (Ectolechiaceae). - Nova Hedwigia 59: 517-523.

Santesson, R. 1952. Foliicolous lichens I. A revision of the obligately foliicolous, lichenized fungi. - Symb. Bot. Ups. 12: $1-590$.

Sérusiaux, E. 1986. The nature and origin of campylidia in lichenized fungi. - Lichenologist 18: 1-25.

- 1995. Further new lichen species producing campylidia or complex conidiomata. - Bibl. Lichenol. 58: 411-431.

Vězda, A. 1986. Neue Gattungen der Familie Lecideaceae s. lat. (Lichenes). - Folia Geobot. Phytotax., Praha, 21: 199219 